\title{
The shift in the balance between osteoblastogenesis and adipogenesis of mesenchymal stem cells mediated by glucocorticoid receptor
}

\author{
Lizhi Han¹, Bo Wang ${ }^{2}$, Ruoyu Wang ${ }^{1}$, Song Gong ${ }^{1}$, Guo Chen ${ }^{1}$ and Weihua Xu ${ }^{1 *}$ (D)
}

\begin{abstract}
Mesenchymal stem cells (MSCs) are multipotent cells capable of differentiating into several tissues, such as bone, cartilage, and fat. Glucocorticoids affect a variety of biological processes such as proliferation, differentiation, and apoptosis of various cell types, including osteoblasts, adipocytes, or chondrocytes. Glucocorticoids exert their function by binding to the glucocorticoid receptor (GR). Physiological concentrations of glucocorticoids stimulate osteoblast proliferation and promote osteogenic differentiation of MSCs. However, pharmacological concentrations of glucocorticoids can not only induce apoptosis of osteoblasts and osteocytes but can also reduce proliferation and inhibit the differentiation of osteoprogenitor cells. Several signaling pathways, including the Wnt, TGF $\beta /$ BMP superfamily and Notch signaling pathways, transcription factors, post-transcriptional regulators, and other regulators, regulate osteoblastogenesis and adipogenesis of MSCs mediated by GR. These signaling pathways target key transcription factors, such as Runx2 and TAZ for osteogenesis and PPARY and C/EBPs for adipogenesis.

Glucocorticoid-induced osteonecrosis and osteoporosis are caused by various factors including dysfunction of bone marrow MSCs. Transplantation of MSCs is valuable in regenerative medicine for the treatment of osteonecrosis of the femoral head, osteoporosis, osteogenesis imperfecta, and other skeletal disorders. However, the mechanism of inducing MSCs to differentiate toward the osteogenic lineage is the key to an efficient treatment. Thus, a better understanding of the molecular mechanisms behind the imbalance between GR-mediated osteoblastogenesis and adipogenesis of MSCs would not only help us to identify the pathogenic causes of glucocorticoid-induced osteonecrosis and osteoporosis but also promote future clinical applications for stem cell-based tissue engineering and regenerative medicine. Here, we primarily review the signaling mechanisms involved in adipogenesis and osteogenesis mediated by GR and discuss the factors that control the adipo-osteogenic balance.
\end{abstract}

Keywords: Mesenchymal stem cells, Glucocorticoid receptor, Glucocorticoids, Osteonecrosis, Osteoporosis, Osteoblastogenesis, Adipogenesis, Stem cell therapy

\section{Introduction}

Mesenchymal stem cells (MSCs) are capable of selfrenewal, with the pluripotent potential to differentiate into mesenchymal tissues, including bone, cartilage, fat, muscle, tendon, and marrow stroma [1]. When cultured in vitro, MSCs have a stable phenotype and display a monolayer and can be induced to differentiate into

\footnotetext{
* Correspondence: xuweihua@hust.edu.cn

'Department of Orthopaedics, Union Hospital, Tongji Medical College, Huazhong University of Science and Technology, Wuhan 430022, China Full list of author information is available at the end of the article
}

osteoblasts, adipocytes, or chondrocytes [2]. Besides, MSCs possess immunomodulatory functions without immunogenicity that make them ideal candidates for use in the repair of tissue damage and treatment of inflammatory diseases [3]. MSCs hold great potential in regenerative medicine for the treatment of degenerative musculoskeletal conditions like osteoarthritis (OA) [4] and other clinical conditions such as osteogenesis imperfecta, osteonecrosis, and osteoporosis [5-7].

Glucocorticoids (GCs) are steroid hormones that are essential for life and play a vital role in health and

(c) The Author(s). 2019 Open Access This article is distributed under the terms of the Creative Commons Attribution 4.0 International License (http://creativecommons.org/licenses/by/4.0/), which permits unrestricted use, distribution, and 
disease. Endogenous GCs are primarily secreted by the adrenal glands and are involved in the modulation of the stress response and circadian rhythm. The pharmacological applications of GCs include use as potent immunosuppressant agents to treat chronic inflammatory diseases such as asthma, allergic shock, arthritis, and inflammatory bowel disease [8]. The physiological and pharmacological effects of GCs are mediated by the glucocorticoid receptor (GR) [9]. GCs act on virtually all types of cells through the GR, mediating important physiological effects via changes in gene expression and signaling. The GR is an intracellular protein that is ubiquitously expressed in almost every cell of the organism and interacts with chromatin to modulate the activity of numerous transcription factors in a cell type-specific manner.

Normal physiological levels of GCs are essential for development, metabolism, normal osteoblast differentiation, and bone formation. However, long-term exposure to GCs at pharmacological dosages is attributed to skeletal side effects, including osteoporosis, fracture, and osteonecrosis $[10,11]$. Glucocorticoid-induced fractures occur in 30 to $50 \%$ of patients receiving long-term GC therapy, while osteonecrosis occurs in 9 to $40 \%$ of the patients [12, 13]. MSCs isolated from patients with steroid-induced osteonecrosis of the femoral head (SONFH) display an inherent defect in osteogenesis, which suggests that the osteonecrosis resulted from an insufficient repair mechanism [14]. Also, the in vitro culture of bone marrow-derived MSCs (BM-MSCs) from patients with osteoporosis is more likely to result in adipogenic differentiation rather than osteogenic differentiation [15]. Similar results can be found in dexamethasone (DEX)-induced osteoporotic mouse model that BM-MSCs from Dex-treated mice cultured in vitro are more likely to differentiate into adipocytes instead of osteoblasts than those from control mice [16].

The ability of the GCs to mediate a switch in the fate of MSCs has a significant impact on the skeletal system and is of clinical significance in stem cell-based tissue engineering and regenerative medicine. This review focuses on how GCs regulate the lineage commitment of MSCs through different signaling pathways, transcription factors, and post-transcriptional regulators, among other regulators. This remarkable advance in understanding molecular mechanisms behind the fate of MSCs mediated by GR will provide new insights into mitigating the adverse effects of GCs on bone and joints. Besides, the opinions presented in this review will provide new strategies for stem cell-based bone repair and regeneration in the future.

\section{Source and heterogeneity of MSCs}

Mesenchymal stem cells (MSCs) were initially isolated from rat bone marrow (BM) and described as colonyforming fibroblasts (CFU-F) in 1976 [17]. These colony- forming cells have since been named "mesenchymal stromal cells" or "mesenchymal stem cells." After that, other tissue-derived human MSCs have been found, such as human MSCs isolated from the adipose tissue, umbilical cord matrix, periosteum, synovium, tendon, lung, and dental pulp among others $[18,19]$. Although the word "stem" has been used in numerous articles, "stemness" is a more strict term for defining MSCs with the ability to repair tissues in vivo [20]. In recent years, the term "tissue stem cells" has been replaced with "skeletal stem cells (SSCs)" as a new term for these cells [21, 22].

Heterogeneity in MSCs occurs not only in the proliferative and differentiation abilities among individual donor tissues but also among MSCs isolated from the same donor tissue. Besides, MSCs derived from different tissues or individual donors exhibit heterogeneity in marker profiles, gene expression patterns, and propensity to differentiate into particular lineages [23]. Contrary to the classical view of differentiation, the findings of transcriptome analysis in mice revealed that osteogenic and adipogenic signatures are not mutually exclusive, and specific subtypes of skeletal progenitors may coexpress alternative lineage-specific genes [24]. Although BM-MSCs are widely used for stem cell therapy, these in vitro cultured cells are highly heterogeneous, with the potential to differentiate into many overlapping lineages, such as osteoblasts, chondrocytes, adipocytes, fibroblast, endothelial, and stromal cells. These promiscuous cells are likely to form a population including various types of stem cells rather than a homogeneous population of SSCs [25]. The application of single-cell analysis and lineage-tracing technologies in mice and humans revealed that SSCs could differentiate into osteoblasts, chondrocytes, and stromal cells, but not adipocytes. The report also revealed that perisinusoidal MSCs could give rise to adipocytes $[25,26]$.

\section{Glucocorticoid receptor}

The GR, encoded by the NR3C1 gene, is a member of the nuclear receptor superfamily of ligand-activated transcriptional factor. It mediates cellular effects of GCs and is widely expressed in almost all cells of the body [27, 28]. The GR consists of four major domains: the $\mathrm{NH} 2$-terminal transactivation domain (NTD) or activation function 1 (AF-1), DNA-binding domain (DBD), hinge region, and ligand-binding domain (LBD) [29]. The multiple domains of the GR are involved in ligand binding, DNA binding, and transcriptional regulation, which constitute the molecular basis of GC actions via the GR [8]. The GR controls transcription and modulates diverse physiological processes such as cell proliferation, differentiation, and apoptosis. Also, GR regulates gene transcription, either positively or negatively, by transactivation or transrepression, respectively [8]. After 
entering the cell, the ligand (GCs) binds to the receptor as part of large heterocomplexes (Fig. 1). This widely studied complex consists of several proteins, including heat shock proteins (e.g., HSP90 and HSP70), immunophilins such as FK506-binding proteins (FKBPs), CyP-40, P23, and perhaps few other proteins [30-32]. In the absence of ligand binding, the GR is primarily located in the cytoplasm, combined with immunophilins such as FKBP51 and FKBP52, heat shock/chaperone proteins (like Hsp70, Hsp90, and p23), and other proteins [31-34]. Hsp70 identifies newly synthesized GR molecules and binds to the LBD of GR [35, 36]. Another essential protein, co-chaperone protein Hsp40, promotes the combination of $\mathrm{Hsp} 70$ with GR to form a complex which has a low binding affinity to GCs. This complex allows for combination with the Hsp90 dimer, which enhances the affinity of the GR to the ligand [37]. While entering the cell, the activity and bioavailability of GCs are controlled by $11 \beta$-hydroxysteroid dehydrogenases

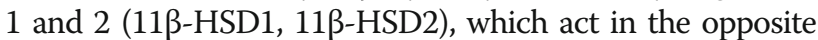
manner [38]. The 11 $\beta$-HSD1 converts cortisone (the inactive hormone form) to cortisol (the active hormone form), while $11 \beta-H S D 2$ oxidizes cortisol to cortisone. The binding of GCs to the LBD of GR activates GR as a result of the complex being disassembled. Subsequently, the "activated" receptor enters the nucleus, where it interacts with critical sites of the regulated genes.

Alternative splicing of the pre-mRNA of the human glucocorticoid receptor (hGR) produces the GR $\alpha, G R \beta$, GRy, GR-A, and GR-P isoforms [39-42] (Fig. 2). Isoforms
GR $\alpha$ and GR $\beta$ are generated by alternative splicing of the GR transcript at exon 9 [43] and are 777 and 742 amino acids in length, respectively. Furthermore, isoforms GR $\alpha$ and GR $\beta$ are highly homologous in structure with different carboxyl termini. The GR $\alpha$ carboxy-terminus forms the LBD and is composed of 50 amino acids, while GR $\beta$ has only 15 carboxy-terminal amino acids and thus cannot bind GCs [44]. The GR $\alpha$ isoform is the most abundant and "classical" GR protein, while the GR $\beta$ isoform can regulate the expression of many genes that are not sensitive to regulation by GR $\alpha$ [45-47]. Being a ligand-dependent transcription factor, the binding of GR $\alpha$ to GCs can activate specific glucocorticoid response element (GRE) and regulate the expression of glucocorticoid-responsive genes. In contrast, hGR $\beta$ plays a dominant-negative role in the transcriptional activity of hGR $\alpha$ by occupying GRE target sites in a dosedependent manner [39] and may contribute to GC resistance [48]. Real-time PCR and Western blot analysis results by YUN S P et al. showed that treatment with DEX $\left(10^{-6}\right.$ $\mathrm{M})$ increases the expression level of hGR $\alpha$ mRNA and protein, but does not change hGR $\beta$ expression [49]. The GR $\gamma$ isoform is produced by the insertion of an additional arginine between the two zinc fingers of the DBD of the GR [50]. Increased in vitro expression of GR $\gamma$ is associated with GC resistance in initial acute lymphoblastic leukemia [51]. Furthermore, the GR $\gamma$ isoform regulates genes that are not regulated by $G R \alpha$, as revealed by expression profiling with GR $\gamma$ overexpression [52]. In contrast to GR $\gamma$, the GR-A and GR-P isoforms are prevalent in some types of cancers,

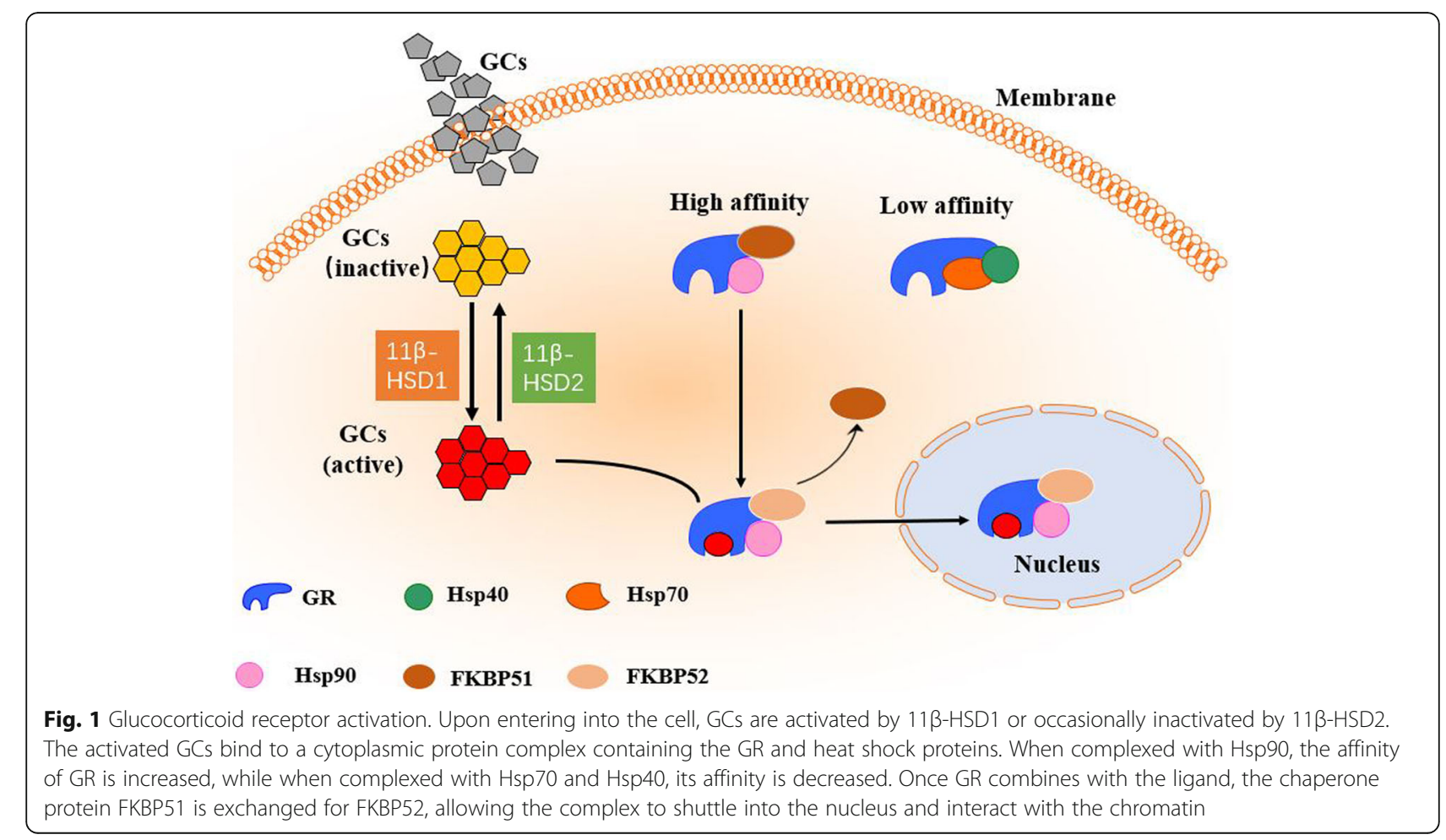




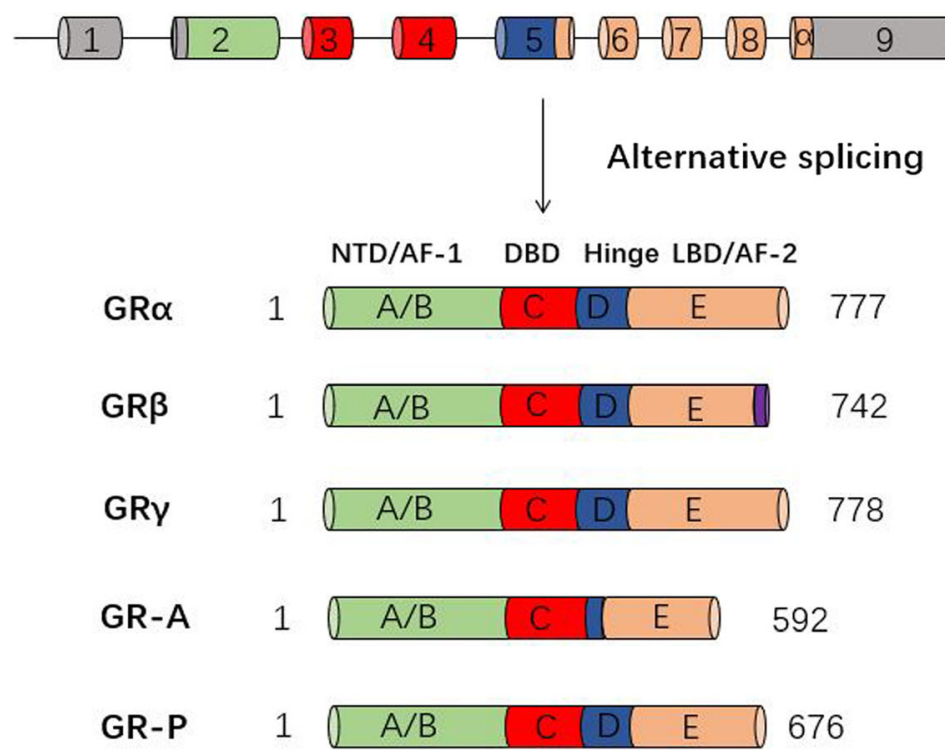

Fig. 2 Domain structure of hGR splice variants and isoforms. The primary transcript of hGR consists of nine exons. Exon 1 constitutes the 5'untranslated region ( $5^{\prime} \mathrm{UTR}$ ), whereas the protein-coding region is made up of exons 2 to 9 . In this process, the A/B-domain or NH2-terminal transactivation domain (NTD) containing the ligand-independent activation function 1 (AF-1) is encoded primarily by exon 2, the C-domain with the DNA-binding domain (DBD) is encoded by exons 3 and 4, and the D-domain or hinge region involved in nuclear localization is encoded by exon 5, while the other exons (up to exon 9) encode the E-domain including the ligand-binding domain (LBD) and a nuclear localization signal, which participates in the dimerization and Hsp90 binding

such as myeloma and leukemia, and cannot bind GCs due to exon deletions in their LBD $[53,54]$.

\section{Dose-dependent effect of GCs on the proliferation, osteogenesis, and adipogenesis of MSCs}

Physiological levels of GCs stimulate osteoblast proliferation and promote osteogenic differentiation of MSCs. In contrast, pharmacological doses of GCs can not only induce apoptosis of osteoblasts and osteocytes but also reduce proliferation and inhibit the differentiation of osteoprogenitor cells. These effects of GCs are mediated by the GR [8]. It was shown that lower concentrations $\left(10^{-9} \mathrm{M}\right)$ of DEX promote the proliferation of rat BMMSCs, whereas higher levels $\left(10^{-7}\right.$ and $\left.10^{-6} \mathrm{M}\right)$ inhibit proliferation [55]. Treatment of human BM-MSCs with DEX showed that DEX at the concentration of $10^{-8} \mathrm{M}$ positively regulates the transcription of genes involved in cell proliferation [56]. The inhibitory effect of excess GC on the proliferation of osteoblastic lineage cells leads to GC-induced osteoporosis (GIO). Therefore, GCs have an impact on different mitogenic signaling pathways and attenuate the progression of the osteoblast cell cycle in a developmental stage-specific manner [57]. The Wnt signaling pathway can prevent apoptosis of osteoblasts and accelerate osteoblast cell cycle progression and thereby increase proliferation [58]. In murine osteoblastic MC3T3E1 cells, the inhibition of cell cycle progression by DEX [59] is partly due to abnormal GR activation and subsequent p53 activation [60]. In MC3T3-E1 cells also, attenuation of proliferation is a prerequisite for osteoblast differentiation [59].

Besides, physiological levels of GCs play a positive regulatory role in osteoblast differentiation and bone formation, both in vitro and in vivo [61, 62]. A proper concentration of DEX (up to $10^{-9}-10^{-8} \mathrm{M}$ ) is needed to trigger differentiation in human osteoblasts in a specific time-window, partly because it can increase the activity of alkaline phosphatase (ALP) during the early stages of osteoblast development [63]. The Wnt signaling pathway plays an essential role in the lineage commitment of MSCs from an adipogenic lineage into an osteoblastic lineage. The secreted frizzled-related protein 1 , an inhibitor of the Wnt pathway, is downregulated by physiological concentrations of GCs [64]. Therefore, basal concentrations of GCs are crucial for the release of Wnt proteins, which then activates the canonical Wnt pathway in a paracrine manner (Fig. 3). Subsequently, $\beta$ catenin accumulates in the nucleus, and expression of the critical transcription factor Runx2 for osteoblast differentiation is promoted [8].

The use of excessive GC such as DEX suppresses osteogenic differentiation of MSCs and bone formation $[16,65]$ and shifts the lineage commitment of MSCs from the osteoblastic lineage to the adipocyte lineage $[16,66]$. When the concentration of DEX is higher than $10^{-8} \mathrm{M}$, the osteogenic differentiation capacity of MSCs can be attenuated. It was indicated that $\mathrm{C} 3 \mathrm{H} 10 \mathrm{~T} 1 / 2$ cells treated with high-dose DEX $\left(10^{-6}-10^{-7} \mathrm{M}\right)$ have higher 


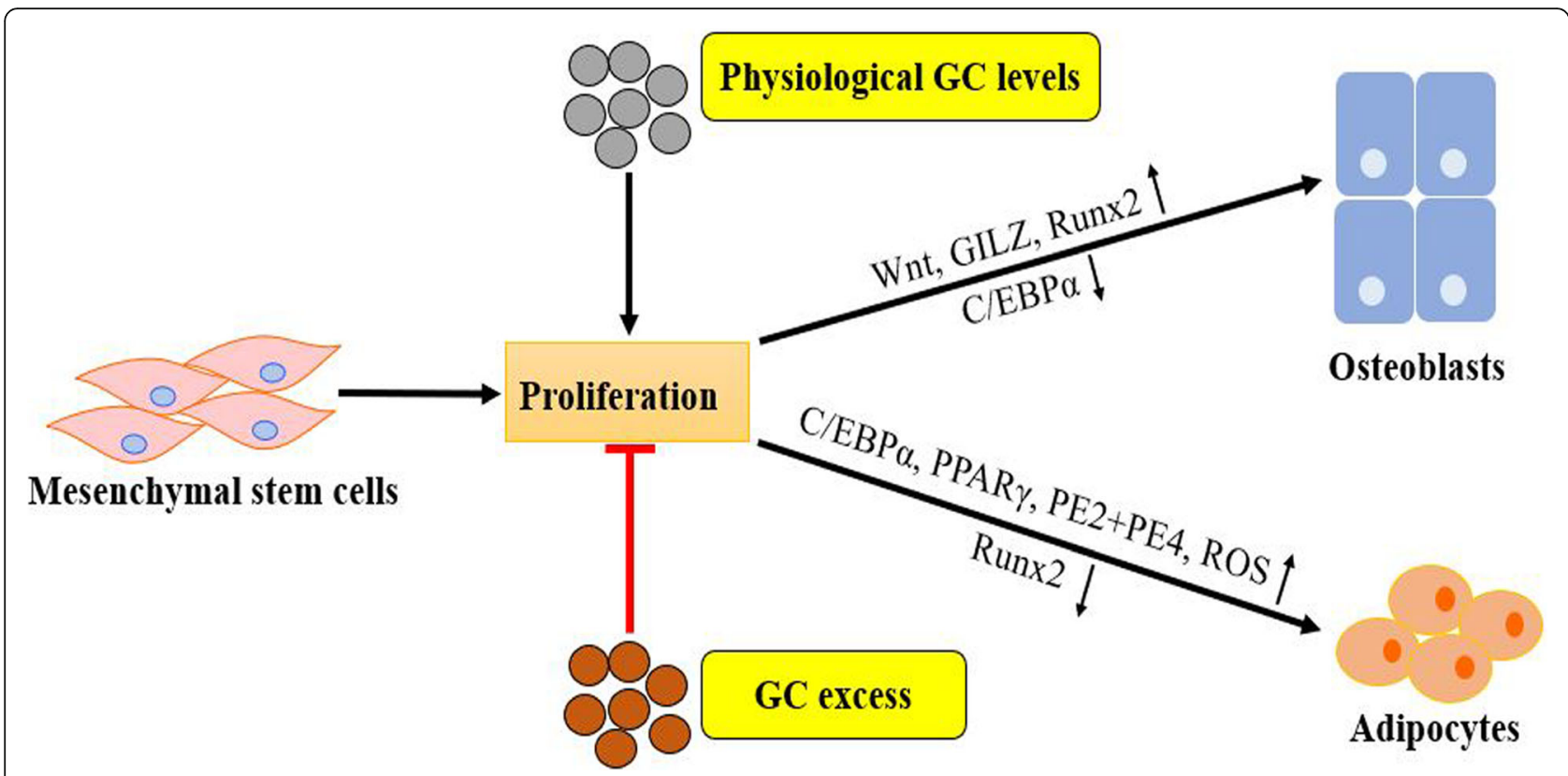

Fig. 3 Effects of physiological and pharmacological concentrations of GCs on MSCs lineage commitment: excess GC inhibits MSC proliferation and shifts the MSC differentiation commitment toward adipogenic differentiation at the expense of osteogenesis by upregulating specific adipogenic transcription factors (PPARY, C/EBPa) and prostaglandin receptors (PE2+PE4) and ROS or by inhibiting osteoblastogenic inducers (downregulation of Runx2). On the other hand, physiological GC levels can stimulate MSC proliferation and promote osteogenic differentiation of MSCs under certain conditions. Canonical Wnt signaling and GILZ might be implicated in this process

adipogenic differentiation potential, whereas low-dose DEX $\left(10^{-8}-10^{-9} \mathrm{M}\right)$ cannot stimulate this potential [16]. The mechanisms underlying the effects of excess GCs or pharmacological dosages of GCs through the GR on osteogenic and adipogenic differentiation of MSCs are discussed in Table 1.

\section{Major signaling pathways involved in adipo- osteogenic differentiation of MSCs by excess GCs}

The differentiation commitment of MSCs is regulated by several signaling pathways which can promote MSCs to differentiate into osteoblasts, adipocytes, chondrocytes, and stromal cells. Different signaling molecules can also regulate the differentiation commitment of MSCs via a variety of signaling pathways. The various GR-mediated signaling pathways that affect osteogenic or adipogenic differentiation of MSCs are represented in Table 1.

\section{Wnt/ $\beta$-catenin signaling}

As an evolutionarily conserved signaling pathway, the Wnt signaling pathway has been widely studied and is crucial for renewal, proliferation, and differentiation of stem cells during embryonic development and adult tissue homeostasis [102]. The binding of Wnt ligands, such as secreted frizzled-related proteins (SFRPs), to the frizzled receptor and low-density lipoprotein receptorrelated protein 5 or 6 (LRP5 or LRP6) can stabilize $\beta$ catenin by preventing its phosphorylation and activate the Wnt pathway [103]. Accumulating evidence suggests that the activated Wnt signaling promotes osteogenic differentiation [104] and inhibits adipogenic differentiation of MSCs [105]. Glucocorticoids (GCs) affect Wnt signaling through different mechanisms. On the one hand, high doses of GCs attenuate osteoblast differentiation in mice in vitro by reducing the expression of Wnt7b and Wnt10. On the other hand, high GC doses further enhance the expression of inhibitors of the Wnt signaling pathway, such as dickkopf-1 (DKK1) [67, 68], SFRPs $[69,70]$, Wnt inhibitory factor-1(Wif1), and sclerostin [71]. Accordingly, knocking down DKK1 attenuates the negative effects of GCs on bone mass in rats [72]. Moreover, serum from children who have been treated with high GC doses for long-term express elevated levels of DKK1 [106].

\section{TGF $\beta / B M P$ superfamily}

Transforming growth factor-beta (TGF $\beta$ )/bone morphogenic protein (BMP) signaling pathway plays dual roles in regulating osteogenic and adipogenic differentiation of MSCs [107]. The TGF- $\beta$ superfamily only exists in mammals and can be divided into three closely related subtypes: TGF- $\beta 1-T G F-\beta 3$, and BMPs. The BMPs, which represent the largest subgroup of this superfamily, belong to the TGF $\beta 1$ family [108]. By binding to transmembrane serinethreonine kinase receptors (termed type I and type II), TGF $\beta / B M P$ ligands activate the canonical Smad-dependent 
Table 1 Factors involved in the regulation of osteogenesis and adipogenesis by excess GC

\begin{tabular}{|c|c|c|c|c|c|}
\hline Factors & Species & Cell type & In vitro/in vivo study & Molecular mechanism & $\operatorname{Ref}(\mathrm{s})$ \\
\hline \multicolumn{6}{|l|}{ Signaling pathways } \\
\hline Wnt/ $\beta$-catenin signaling & $\begin{array}{l}\text { Human } \\
\text { Rat, mice }\end{array}$ & $\begin{array}{l}\text { Osteoblasts } \\
\text { BM-MSCs } \\
\text { MC3T3-E1 cells }\end{array}$ & $\begin{array}{l}\text { In vitro } \\
\text { In vitro, in vivo }\end{array}$ & $\begin{array}{l}\text { Enhance Wnt signaling pathway inhibitors } \\
\text { (such as DKK1, SFRPs, Wif1, and sclerostin); } \\
\text { downregulate Wnt7b and Wnt10 }\end{array}$ & [67-72] \\
\hline TGF $\beta / B M P$ superfamily & Mice & MC3T3-E1 cells & In vitro & $\begin{array}{l}\text { Suppress BMP2; enhance BMP2 antagonists } \\
\text { (follistatin and Dan) }\end{array}$ & {$[73,74]$} \\
\hline Notch signaling & Mice & MC3T3-E1 cells & $\begin{array}{l}\text { In vitro } \\
\text { In vivo }\end{array}$ & $\begin{array}{l}\text { Enhance Notch1 and Notch 2; downregulate } \\
\text { Notch target genes (such as Hey1, Hey2, } \\
\text { and HeyL) }\end{array}$ & {$[75,76]$} \\
\hline \multicolumn{6}{|l|}{$\begin{array}{l}\text { Transcription factors/ } \\
\text { post-transcriptional } \\
\text { regulators }\end{array}$} \\
\hline Runx2 & Rat & $\begin{array}{l}\text { Osteoblast } \\
\text { BM-MSCs }\end{array}$ & $\begin{array}{l}\text { In vitro } \\
\text { In vitro }\end{array}$ & $\begin{array}{l}\text { Inhibit Runx2; over-expression of Run×2 } \\
\text { antagonizes GC-induced adipogenesis }\end{array}$ & [77-79] \\
\hline PPARY and C/EBPs & $\begin{array}{l}\text { Mice } \\
\text { Human }\end{array}$ & $\begin{array}{l}\text { BM-MSCs } \\
\text { 3T3-L1 preadipocytes } \\
\text { BM-MSCs }\end{array}$ & $\begin{array}{l}\text { In vitro } \\
\text { In vitro } \\
\text { In vitro }\end{array}$ & $\begin{array}{l}\text { Enhance PPARY and C/EBP members (C/EBPa, } \\
\beta \text {, and } \delta) \text {; Downregulate C/EBP } \beta \text { in the later } \\
\text { stage of the adipogenesis process }\end{array}$ & {$[16,80-82]$} \\
\hline $\mathrm{TAZ}$ & $\begin{array}{l}\text { Rat } \\
\text { Mice }\end{array}$ & $\begin{array}{l}\text { BM-MSCs } \\
\text { 3T3-L1 preadipocytes }\end{array}$ & $\begin{array}{l}\text { In vitro } \\
\text { In vitro }\end{array}$ & $\begin{array}{l}\text { Inhibit TAZ and ALP; overexpression of TAZ } \\
\text { suppresses adipogenesis and promotes the } \\
\text { trans-differentiation of preadipocytes into } \\
\text { osteocytes }\end{array}$ & {$[83,84]$} \\
\hline GILZ & $\begin{array}{l}\text { Mice } \\
\text { Mice }\end{array}$ & $\begin{array}{l}\text { BM-MSCs } \\
\text { 3T3-L1 preadipocytes }\end{array}$ & $\begin{array}{l}\text { In vitro } \\
\text { In vivo }\end{array}$ & $\begin{array}{l}\text { Activate GILZ; overexpression of GILZ } \\
\text { enhances osteogenesis, inhibits adipogenesis } \\
\text { by inhibiting PPARY2 and C/EBPa, and GILZ } \\
\text { inhibits PPAR- } \gamma 2 \text { mediated by C/EBP- } \delta\end{array}$ & [85-88] \\
\hline Prostaglandin E2 & Human & BM-MSCs & In vitro & $\begin{array}{l}\text { Induce prostaglandin receptors to inhibit } \\
\text { osteogenesis and enhance adipogenesis }\end{array}$ & [89] \\
\hline \multicolumn{6}{|l|}{$\begin{array}{l}\text { MicroRNAs' detailed } \\
\text { information is shown } \\
\text { in Table } 2\end{array}$} \\
\hline Long non-coding RNAs & $\begin{array}{l}\text { Rat } \\
\text { Human }\end{array}$ & $\begin{array}{l}\text { BM-MSCs } \\
\text { BM-MSCs }\end{array}$ & $\begin{array}{l}\text { In vitro } \\
\text { In vitro }\end{array}$ & $\begin{array}{l}\text { Downregulate IncRNA TCONS_00041960 and } \\
\text { IncRNA RP11-154D6; IncRNA TCONS_00041960 } \\
\text { enhances osteogenesis and inhibits adipogenesis } \\
\text { by targeting miR-204-5p and miR125a-3p }\end{array}$ & {$[96,97]$} \\
\hline \multicolumn{6}{|l|}{ Other regulators } \\
\hline Oxidative stress & $\begin{array}{l}\text { Mice } \\
\text { Rat }\end{array}$ & $\begin{array}{l}\text { Osteoblasts } \\
\text { Osteoblasts }\end{array}$ & $\begin{array}{l}\text { In vitro } \\
\text { In vitro }\end{array}$ & $\begin{array}{l}\text { Increase ROS to decrease Cbfa1 expression; } \\
\text { N-acetylcysteine mitigates the detrimental } \\
\text { effects of GC-induced oxidative stress }\end{array}$ & {$[98,99]$} \\
\hline FilGAP-FLNA & Human & BM-MSCs & In vitro & $\begin{array}{l}\text { Antagonize mechanical forces; FLNA and } \\
\text { c-Tubulin play an important role in mechanical } \\
\text { regulation during osteogenesis and adipogenesis }\end{array}$ & {$[100,101]$} \\
\hline
\end{tabular}

Factors, signaling pathways, transcription factors and post-transcriptional regulators, and other regulators, involved in the regulation of osteogenesis and adipogenesis by GC excess; Species, species involved in study; Cell type, cell type involved in the study; In vitro/nn vivo Study, study performed in vitro or in vivo; Molecular mechanism, molecular mechanism involved in the regulation of osteogenesis or adipogenesis by excess GC; References, references related to the study in this table

signaling pathways (TGF $\beta /$ BMP ligands, receptors, Smads) and the non-canonical Smad-independent signaling pathway such as p38 mitogen-activated protein kinase (MAPK) pathway [109]. Following TGFB/BMP induction, either the Smad or p38 MAPK pathway can regulate the expression of the runt-related gene 2 (Runx2) [108] and the peroxisome proliferator-activated receptor-gamma (PPAR $\gamma$ ) [107]. Also, the osteogenic or adipogenic differentiation of MSCs is directly controlled by alteration in the expression levels of lineage-specific transcription factors such as Runx2 or
PPARy. In vitro, treatment with BMP-2, a key regulator of osteoblast differentiation, enhances osteoblast differentiation by increasing the expression of Runx2 gene and ALP in several types of MSCs, such as human marrow stromal cell line [110] and human adipose-derived stem cells (ASCs) [111]. Glucocorticoids (GCs) suppress the expression of BMP2 gene, which can antagonize the GCinduced inhibitory effects of differentiation depending on the differentiation stage in osteoblastic MC3T3-E1 cells culture model [73]. In MC3T3-E1 cells also, GCs increase 
the mRNA expression of follistatin and Dan, which antagonize BMP2 [74].

\section{Notch signaling}

Notch signaling functions as a molecular gate and is closely correlated with binary cell fate decisions during embryonic development and homeostatic maintenance of adults [112-115]. Mammals have five classic Notch ligands (Jagged-1 and Jagged-2, Delta-like 1, 3, and 4) and four transmembrane notch receptors (Notch1-4) [116]. Notch ligands are single-pass transmembrane proteins and play the dual roles of activating and repressing Notch signaling [117]. The trans-interaction of a Notch ligand-receptor results in receptor activation, whereas a cis-interaction in the same cell inhibits Notch signaling [118]. The Notch signaling pathway is activated by an interaction between a membranous Notch receptor and the membrane-bound ligand of adjacent cells, which lead to proteolytic cleavage of the Notch receptor. After that, the Notch intracellular domain is released and translocates into the nucleus to regulate the expression of related genes. The role of Notch signaling in the lineage decision of MSCs is essential and complicated. As revealed in the 3T3-L1 pre-adipocyte model, for instance, Notch signaling plays dual roles in adipogenic differentiation [119]. Similar to the dual roles in adipogenesis, the interaction between Notch1 and BMP-2, a TGF $\beta$ ligand, enhances osteogenic differentiation and ectopic bone formation of MC3T3-E1 cells in vivo [120]. However, the overexpression of Notch1 inhibits osteogenesis of mice BM ST-2 cells by suppressing Wnt/ $\beta$-catenin [121]. The findings of a genome-wide association study indicate that the JAG1 gene, which encodes the Notch ligand Jagged-1, is associated with bone mineral density and osteoporotic fractures [122]. Although GCs can inhibit osteoblast differentiation by stimulating mRNA expression of Notch1 and Notch 2, GCs do not regulate the expression of Notch ligands in MC3T3-E1 cells [75]. Additionally, in vivo administration of GCs inhibits the expression of Notch target genes such as Hey1, Hey2, and HeyL in osteoblasts [76].

\section{Transcription factors and post-transcriptional regulators involved in adipo-osteogenic differentiation of MSCs by excess GCs}

The lineage commitment of MSCs is also modulated by transcription factors or post-transcriptional regulators, which can directly or indirectly act on target genes of various signaling pathways, thus initiating and promoting osteogenic or adipogenic differentiation of MSCs. Glucocorticoids (GCs) can positively or negatively regulate the expression of multiple transcription factors (e.g., PPAR $\gamma$, Runx2) and post-transcriptional regulators (e.g., miRNAs, lncRNAs), as shown in Table 1, thereby affecting the differentiation of MSCs into osteoblasts or adipocytes (Fig. 3).

\section{Runx2}

Runt-related transcription factor 2 (Runx $2 / \mathrm{Cbfa} 1)$ is an essential differentiation factor and a key regulator of osteoblast differentiation in mammals [123-125]. The critical function of Runx2 in osteogenesis was elucidated in mice with a homozygous Runx2 mutation. The Run $x 2^{-/-}$mice died soon after birth and exhibited an incompletely ossified skeleton [126]. According to a study, GCs can rapidly inhibit the expression of functional Runx2 in nuclear extracts from the GC-treated primary osteoblast cultures of fetal rat [77]. In another study, DEX-activated GR exerts various degrees of antagonistic effects on Runx2 during osteoblast differentiation in cultures of BM-derived ST2 pluripotent mesenchymal cells [78]. Besides, the overexpression of Runx2 can antagonize the effect of GCinduced adipogenic differentiation on primary cultured rat BM-MSCs [79].

\section{PPARY and C/EBPs}

The nuclear receptor peroxisome proliferator-activated receptor-gamma (PPAR $\gamma$ ) and CCAAT/enhancer-binding proteins (C/EBPs) are transcription factors involved in the regulation of adipogenesis [80, 127-129]. Glucocorticoids (GCs) induce the expression of PPAR $\gamma$ and $\mathrm{C} /$ EBP members $(\mathrm{C} / \mathrm{EBP} \alpha, \beta$, and $\delta)$, leading to enhanced adipogenic differentiation and decreased osteoblastogenesis in BM-MSCs $[16,81,82]$. Meanwhile, the binding of DEX to endocellular GR can activate the expression of C/EBPS [80]. The expression of PPAR $\gamma$ and C/EBP $\alpha$ is upregulated during the entire adipogenesis process of 3T3-L1 preadipocytes, while the expression of $\mathrm{C} / \mathrm{EBP} \beta$ is downregulated in the later stage of the process [80].

\section{TAZ}

The transcriptional co-activator with PDZ binding motif (TAZ) is a transcriptional co-activator that regulates the differentiation of MSCs into osteoblasts or adipocytes [125]. The expression of TAZ promotes osteogenic differentiation of MSCs by coactivating Runx2-dependent gene transcription and blocks adipogenic differentiation of MSCs by inhibiting PPAR $\gamma$-dependent gene transcription [130-132]. The expression of TAZ and ALP were enhanced by treatment with DEX at a concentration of $10^{-8} \mathrm{M}$ during osteoblastic differentiation of rat BMMSCs, whereas a higher concentration $\left(10^{-7} \mathrm{M}\right)$ of DEX strongly suppressed the expression of TAZ and ALP [83]. The expression of TAZ is inhibited by a high concentration of DEX at the transcriptional level during the differentiation of 3T3-L1 preadipocytes into mature adipocytes. Furthermore, overexpression of TAZ suppresses 
adipogenesis and trans-differentiates 3T3-L1 preadipocytes into osteocytes [84].

\section{Glucocorticoid-induced leucine zipper}

Glucocorticoid-induced leucine zipper (GILZ), one of the GC-induced genes [133], belongs to the leucine zipper protein family and mediates the anti-inflammatory effect of GCs [134-136]. Classic GCs activate GR and transactivate the anti-inflammatory protein GILZ [85]. Overexpression of GILZ promotes osteogenic differentiation of mice BMMSCs [86] and enhances bone acquisition in GILZ transgenic mice [87]. In contrast, inhibition of the expression of PPAR 22 and C/EBPo reduces the adipogenic differentiation capacity of mice BM-MSCs over-expressing GILZ [86]. Another study reported similar results that over-expression of GILZ blocks the differentiation of 3T3-L1 preadipocytes into adipocytes, and GILZ inhibits the expression of PPAR$\gamma 2$ mediated by C/EBP- $\delta$ [88].

\section{Prostaglandin E2}

Prostaglandin E2 (PGE2), a potent lipid mediator and a pro-inflammatory mediator, plays a vital role in skeletal metabolism and bone cell differentiation [137, 138]. Due to the induction of prostaglandin receptors (mainly PE2 and PE4 receptor subtypes) in human BM-MSCs, DEX enables these cells to respond to PGE2 which then shift the lineage commitment of BM-MSCs from osteogenic to adipogenic differentiation [89].

\section{MicroRNAs}

MicroRNAs (MiRNAs) are 18-25-nt long small noncoding RNAs that regulate gene expression at the posttranscriptional level by binding to the $3^{\prime}$ untranslated region (3'UTR) of particular target mRNAs [139, 140]. The binding of miRNAs to target mRNAs results in the degradation of target mRNAs or inhibition of mRNA translation, hence gene silencing [141]. In human BMMSCs, the silencing of either Dicer or Drosha, two key enzymes involved in the biogenesis of miRNA, inhibits differentiation of MSCs into osteoblasts and adipocytes [142]. Accumulating evidence reveals that miRNAs are essential regulators of MSC differentiation and fate decisions [143] (Table 2). For example, miR-29a promotes osteogenic differentiation of human MSCs in vitro by targeting HDAC4, a negative regulator of osteoblast differentiation [90]. In the human mesenchymal precursor cell line hFOB1.19, canonical Wnt signaling promotes transcription of miR-29a, which can potentiate Wnt signaling by inhibiting key Wnt signaling antagonists such as Dkk1 and Kremen2 [91]. The microRNA-29a promotes osteogenic differentiation by inhibiting GCinduced blockage of Wnt signaling in GC-treated rats, and thus, modulating miR-29a signaling is a promising strategy for alleviating GC-induced bone loss [92]. Using
miRNA microarrays and RT-PCR, Li et al. [93] identified nine upregulated miRNAs and seven downregulated miRNAs involved in osteogenic differentiation of DEXinduced human BM-MSCs. Target genes of the upregulated DEX-induced miRNAs include RUNX2, SMAD1, SMAD5, and BMPR2, which promote osteogenic differentiation of human BM-MSCs. Similarly, target genes of the downregulated miRNAs induced by DEX treatment include Sox4, BMP3, HDAC4, and TGF- $\beta 1$, and these inhibit osteogenic differentiation. In another study, miR216a can reverse the inhibitory effect of DEX on osteogenic differentiation of human adipose-derived MSCs in vitro and enhance ectopic bone formation in vivo, by suppressing the expression of c-Cbl [94]. In contrast, miR-708 can promote steroid-induced osteonecrosis of the femoral head (SONFH) and inhibit the osteogenic differentiation of human BM-MSCs in vitro by targeting SMAD3 [95].

\section{Long non-coding RNAs}

Long non-coding RNAs (lncRNAs) are a class of nonprotein coding RNAs with a length of more than 200 nucleotides [144]. Mounting evidence has demonstrated that lncRNAs participate in diverse critical biological processes such as growth and differentiation of various cell types $[145,146]$. Similar to microRNAs, lncRNAs play a critical role in the adipo-osteogenic lineage commitment of MSCs [147-149]. For instance, the lncRNA TCONS_00041960 promotes osteogenic differentiation and suppresses adipogenic differentiation of GC-treated rat BM-MSCs, by directly sponging miR-204-5p and miR125a-3p [96]. In another study, the expression of the lncRNA RP11-154D6 was reduced in human BM-MSCs of patients with SONFH, and its overexpression enhanced osteogenic differentiation while inhibiting adipogenic differentiation [97]. However, more lncRNAs involved in osteogenesis and adipogenesis via GR need to be identified and studied.

\section{Other regulators controlling the balance between osteogenesis and adipogenesis of MSCs}

\section{Oxidative stress}

Oxidative stress represents an unbalanced situation in which the production of reactive oxygen species (ROS) overwhelms the cell's antioxidant systems, causing tissue damage. Mesenchymal stem cells (MSCs) typically have low levels of intracellular ROS and high levels of glutathione, an important antioxidant [150]. As living organisms age, ROS and oxidative stress levels increase, and the two play important roles in age-related bone loss and conversion of adipo-osteogenic differentiation through Wnt, PPARy, and Forkhead box O (FoxO) [151-153]. Increasing evidence indicates that changes in metabolic processes, such as mitochondrial metabolism and oxidative 
Table 2 MiRNAs involved in osteogenesis and adipogenesis of GC-treated MSCs

\begin{tabular}{|c|c|c|c|c|c|c|}
\hline MiRNAs & Species & In vitro/in vivo study & Expression & Functions & Target genes & $\operatorname{Ref}(s)$ \\
\hline MiR-29a & $\begin{array}{l}\text { Human, Rat } \\
\text { Rat }\end{array}$ & $\begin{array}{l}\text { In vitro } \\
\text { In vivo }\end{array}$ & Down & Osteogenesis & HDAC4 & [90-92] \\
\hline MiR-27a & Human & In vitro & Up & $\begin{array}{l}\text { Osteogenesis } \\
\text { and inhibition } \\
\text { of adipogenesis }\end{array}$ & RUNX1, SMAD5, SATB2, LRP6, FOXO1 & {$[93]$} \\
\hline MiR-22 & Human & In vitro & Up & $\begin{array}{l}\text { Osteogenesis } \\
\text { and inhibition } \\
\text { of adipogenesis }\end{array}$ & SMAD4, SATB2, HDAC6 & [93] \\
\hline MiR-23a & Human & In vitro & Up & Osteogenesis & $\begin{array}{l}\text { SATB1, STAT5B, TMEM135, FGF2, NFIB, } \\
\text { SMAD5, IHH, RUNX2 }\end{array}$ & [93] \\
\hline MiR-221 & Human & In vitro & Up & Osteogenesis & Wnt1, Sox4 & [93] \\
\hline MiR-26a & Human & In vitro & Up & Osteogenesis & SMAD1, Wnt5a, SMAD4, TMEM135 & {$[93]$} \\
\hline MiR-130a & Human & In vitro & Up & Osteogenesis & SMAD5, SMAD4, BMPR1B, BMPR2 & [93] \\
\hline MiR-199a-5p & Human & In vitro & Up & Osteogenesis & TMEM135, Sox4 & [93] \\
\hline MiR-196a & Human & In vitro & Up & $\begin{array}{l}\text { Osteogenesis } \\
\text { and inhibition } \\
\text { of adipogenesis }\end{array}$ & COL1A1, COL1A2, COL3A1, FOXO1 & {$[93]$} \\
\hline MiR-155 & Human & In vitro & Up & Osteogenesis & SATB2 & {$[93]$} \\
\hline MiR-21 & Human & In vitro & Down & $\begin{array}{l}\text { Inhibit of } \\
\text { osteogenesis }\end{array}$ & SMAD7, Sox2, TGFBR2 & [93] \\
\hline MiR-140-3p & Human & In vitro & Down & $\begin{array}{l}\text { Inhibit of } \\
\text { osteogenesis }\end{array}$ & Acvr2b, CBL, HDAC4 & {$[93]$} \\
\hline MiR-214 & Human & In vitro & Down & $\begin{array}{l}\text { Inhibit of } \\
\text { osteogenesis } \\
\text { and adipogenesis }\end{array}$ & $\mathrm{CBL}, \mathrm{GSK3} \beta$ & {$[93]$} \\
\hline MiR-744 & Human & In vitro & Down & $\begin{array}{l}\text { Inhibit of } \\
\text { osteogenesis }\end{array}$ & TGF $\beta 1$ & [93] \\
\hline MiR-320a & Human & In vitro & Down & $\begin{array}{l}\text { Inhibit of } \\
\text { osteogenesis }\end{array}$ & CBL, BMP3, HDAC4, Sox4, Acvr2b, TGFBR2 & [93] \\
\hline MiR-320b & Human & In vitro & Down & $\begin{array}{l}\text { Inhibit of } \\
\text { osteogenesis }\end{array}$ & CBL, BMP3, HDAC4, Sox4, Acvr2b, TGFBR2 & [93] \\
\hline MiR-320c & Human & In vitro & Down & $\begin{array}{l}\text { Inhibit of } \\
\text { osteogenesis }\end{array}$ & CBL, BMP3, HDAC4, Sox4, Acvr2b, TGFBR2 & {$[93]$} \\
\hline MiR-216a & $\begin{array}{l}\text { Human } \\
\text { Mice }\end{array}$ & $\begin{array}{l}\text { In vitro } \\
\text { In vivo }\end{array}$ & Up & Osteogenesis & $\mathrm{c}-\mathrm{Cbl}$ & {$[94]$} \\
\hline MiR-708 & Human & In vitro & Up & Inhibition of osteogenesis & SMAD3 & {$[95]$} \\
\hline
\end{tabular}

Species, species involved in study; In vitro/in vivo study, study performed in vitro or in vivo; Expression, expression of miRNAs during osteogenic or adipogenic differentiation of GC-treated MSCs: Up, upregulation, Down, downregulation; Functions, functions of miRNAs during osteogenic or adipogenic differentiation of GC-treated MSCs; Target genes, target genes determined or predicted by the study; References, references related to the study in this table

stress, affect osteogenic and adipogenic differentiation of MSCs [154, 155]. For example, increased ROS generation inhibits the proliferation and osteogenic differentiation of rat BM-MSCs [156]. Low levels of ROS facilitate osteogenesis, whereas high levels of ROS promote adipogenic differentiation of MSCs [150]. Besides, the administration of GCs to mice increases ROS in bone, and GCs suppress Wnt-induced proliferation and osteoblast differentiation of the mice osteoblastic cell line [98] (Fig. 3). Oxidative stress-induced by DEX $\left(10^{-7}, 10^{-6}\right.$, $10^{-5} \mathrm{M}$ ) decreases the Cbfa1 mRNA expression and inhibits differentiation of rat osteoblasts, whereas the antioxidant $N$-acetylcysteine (NAC) can mitigate the damaging effects of DEX-induced oxidative stress [99].

\section{FilGAP-filamin A}

Darling et al. found that human MSC-derived osteoblasts, chondrocytes, and adipocytes exhibit distinct mechanical properties, with osteoblasts being stiffer than chondrocytes, and both being stiffer than adipocytes [157]. This exciting phenomenon demonstrates that cellular differentiation and mechanical properties are correlated. The study also showed that the presence of an appropriate mechanical stimulus could promote osteogenic differentiation and inhibit adipogenic differentiation of rat BMMSCs [158]. Filamin A (FLNA), a cytoskeletal gene, is a member of the high-molecular-mass cytoskeletal family of proteins that cross-link actin filaments and link actin networks to cell membranes [159-161]. The FLNA gene is 
induced by mechanical forces applied through $\beta 1$ integrins $[162,163]$. The Rac GTPase-activating protein (GAP) FilGAP regulates cellular activity such as actin assembly [164] and targets sites of FLNA force transfer [165]. Concomitant upregulation of FLNA and c-Tubulin with cellular elastic modulus indicated that FLNA and c-Tubulin play an essential role in mechanical regulation during adipogenic and osteogenic differentiation of human BMMSCs [100]. On the other hand, mechanical stimuli protect against apoptosis of osteocytes and osteoblasts by activating the focal adhesion kinase (FAK) and extracellular signal-regulated kinases (ERKs) [166]. Meanwhile, GCs antagonize these survival signals by the activation of proapoptotic kinases Pyk2 and c-Jun N-terminal kinase (JNK) [167]. An antagonistic effect, therefore, exists between mechanical forces and GC, governed by FAK/Pyk2 signaling that acts on the Wnt pathway and regulates apoptosis of osteoblasts and osteocytes [101]. The interaction between FilGAP and FLNA in response to mechanical stimuli plays a mechano-protective role in preventing cells from force-induced apoptosis [165].

\section{Conclusion and perspective}

The findings of various studies have demonstrated that GCs can exert a significant effect via several signaling pathways on the shift between osteogenic and adipogenic differentiation of MSCs. These signaling pathways eventually converge at several transcription factors. For osteogenic differentiation, the pathways converge at Runx2 and TAZ and PPAR $\gamma$ and C/EBPs for adipogenic differentiation of MSCs, participating in a series of tightly controlled transcription events [168, 169]. Other transcription factors and post-transcriptional regulators, such as GILZ, PGE2, miRNAs, and lncRNAs, also affect the delicate balance between osteogenic and adipogenic differentiation of MSCs. Besides, other regulators, such as oxidative stress and FilGAP-filamin A, are also involved in osteogenesis and adipogenesis of MSCs.

Based on its function and role in osteoblastogenesis and adipogenesis of MSCs, GR may modify MSC lineage decisions. To reduce the adverse side effects of GC on the skeletal system, such as bone loss, fractures, and osteonecrosis, new and effective therapies that enhance bone formation by stimulating osteoblast differentiation should be developed. Notably, selective GR modulators such as compound A (CpdA) have been proposed. CpdA, a nonsteroidal anti-inflammatory compound, does not induce GR dimerization or transcriptional activation nor does it interfere with osteoblast differentiation in vitro and in vivo [170]. Furthermore, this GR-modulating agent has a bone-sparing effect in mice [171]. We anticipate that leveraging on cell-based screening methods may lead to the development of additional bone-sparing GR ligands. Secondly, agents that activate bone cell-protective effects by modulating GR-mediated pathways could be effective alternatives. Sclerostin, secreted by osteocytes, is an inhibitor of the Wnt signaling which attenuates osteoblast function and differentiation. Excessive GC has been shown to stimulate sclerostin secretion from osteocytes. Neutralizing antibodies against sclerostin, such as romosozumab, can promote Wnt signaling and improve osteoblast function [172]. Elsewhere, it has been reported that miR-29a can suppress the side effects of excessive GCs on osteoblast differentiation in vitro and restore Wnt signaling by regulating $\beta$-catenin acetylation [173]. To prevent the production of excessive ROS levels following GC administration and redirect the MSC fates, effective pharmaceutical strategies such as the use of antioxidants, extracts from natural products, and gene modifications have been proposed to potentiate the therapeutic efficacy of MSCs [174]. In addition, tissue-specific or cell type-specific delivery systems for GCs may minimize the systemic distribution of pharmacological GCs and thus reduce the adverse effects of GCs on skeletal system.

BM-MSCs have been extensively studied and applied in tissue regeneration and stem cell-based therapies, but the numbers of MSCs in BM are relatively low [175, 176]. In contrast, adipose-derived stem cells (ASCs) are easily obtainable and expandable to provide sufficient numbers for therapeutic applications. Megestrol acetate (MA) imparts mitogenic effects on ASCs and increases the proliferation of ASCs via GR phosphorylation [177]. Future studies should compare in vitro results with in vivo preclinical findings and establish stem cell banks based on the heterogeneity of MSC subpopulations. Furthermore, stem cell therapy based on different MSC subgroups with some advantages (e.g., osteogenesis, adipogenesis, chondrogenesis, angiogenesis, immunomodulation, and hematopoiesis support) should be applied to selectively treat various diseases. Although remarkable advancements in the field of stem cell therapy have expanded our understanding of the role played by GC on MSC phenotypes in vitro, the effects of GCs on mesenchymal precursor cells in vivo remains unknown. In vivo studies are, therefore, required to explore the mechanisms of GR on lineage decisions of MSCs to generate ideas that can be used to develop novel therapies that suppress the negative effects of GCs on the skeletal system, and to improve the clinical application of MSCs in tissue engineering and regenerative medicine.

\footnotetext{
Abbreviations

AF-1: Activation function 1; ALP: Alkaline phosphatase; ASCs: Adipose-derived stem cells; BM: Bone marrow; BM-MSCs: Bone marrow-derived MSCs;

BMP: Bone morphogenic protein; C/EBPs: CCAAT/enhancer-binding proteins; DBD: DNA-binding domain; DEX: Dexamethasone; DKK1: Dickkopf-1; ERKs: Extracellular signals regulated kinases; FAK: Focal adhesion kinase; FKBPS: FK506-binding proteins; FLNA: Filamin A; FoxO: Forkhead box O; GAP: GTPase-activating protein; GC(s): Glucocorticoid(s); GILZ: Glucocorticoidinduced leucine zipper; GIO: GC-induced osteoporosis; GR: Glucocorticoid
} 
receptor; GRE: Glucocorticoid response element; HSD: Hydroxysteroid dehydrogenases; HSP: Heat shock protein; JNK: Jun N-terminal kinase; LBD: Ligand-binding domain; LncRNAs: Long non-coding RNAs; LRP: Lowdensity lipoprotein receptor-related protein; MA: Megestrol acetate; MAPK: Mitogen-activated protein kinase; MiRNAs: MicroRNAs; MSCs: Mesenchymal stem cells; NAC: N-Acetylcysteine; NTD: NH2-terminal transactivation domain; OA: Osteoarthritis; PGE: Prostaglandin E; PPARY: Peroxisome proliferator-activated receptor-gamma; ROS: Reactive oxygen species; Runx2: Runt-related transcription factor 2; SFRPs: Secreted frizzled-related proteins; SONFH: Steroid-induced osteonecrosis of the femoral head; SSCs: Skeletal stem cells; TGFß: Transforming growth factorbeta; UTR: Untranslated region; Wif1: Wnt inhibitory factor-1

\section{Acknowledgements}

We would like to thank all the researchers and study participants for their contributions.

\section{Authors' contributions}

WX and LH conceived the study. LH wrote the manuscript and designed the tables. BW designed the figures. RW, SG, and GC contributed to the writing and editing of the manuscript. All authors and participants reviewed the paper and approved the final manuscript.

\section{Funding}

This study was supported by grants 81672155 from the National Natural Science Foundation of China.

\section{Availability of data and materials}

Not applicable.

\section{Ethics approval and consent to participate}

Not applicable.

\section{Consent for publication}

Not applicable.

\section{Competing interests}

The authors declare that they have no competing interests.

\section{Author details}

'Department of Orthopaedics, Union Hospital, Tongji Medical College, Huazhong University of Science and Technology, Wuhan 430022, China. ${ }^{2}$ Department of Rehabilitation, Wuhan No.1 Hospital, Wuhan Hospital of Traditional Chinese and Western Medicine, Wuhan, Hubei Province, China.

Received: 10 August 2019 Revised: 9 November 2019 Accepted: 18 November 2019 Published online: 05 December 2019

\section{References}

1. da Silva ML, Chagastelles PC, Nardi NB. Mesenchymal stem cells reside in virtually all post-natal organs and tissues. J Cell Sci. 2006;1 19(Pt 11):2204-13.

2. MF P, AM M, SC B, RK J, R D, JD M, et al. Multilineage potential of adult human mesenchymal stem cells. Science. 1999;284(5411):143-147.

3. MacFarlane RJ, Graham SM, Davies PS, Korres N, Tsouchnica H, Heliotis M, et al. Anti-inflammatory role and immunomodulation of mesenchymal stem cells in systemic joint diseases: potential for treatment. Expert Opin Ther Targets. 2013;17(3):243-54.

4. Barry F, Murphy M. Mesenchymal stem cells in joint disease and repair. Nat Rev Rheumatol. 2013;9(10):584-94.

5. Horwitz EM, Prockop DJ, Fitzpatrick LA, Koo WW, Gordon PL, Neel M, et al. Transplantability and therapeutic effects of bone marrow-derived mesenchymal cells in children with osteogenesis imperfecta. Nat Med. 1999; 5(3):309-13.

6. Houdek MT, Wyles CC, Collins MS, Howe BM, Terzic A, Behfar A, et al. Stem cells combined with platelet-rich plasma effectively treat corticosteroidinduced osteonecrosis of the hip: a prospective study. Clin Orthop Relat Res. 2018;476(2):388-97.

7. Aghebati-Maleki L, Dolati S, Zandi R, Fotouhi A, Ahmadi M, Aghebati A, et al. Prospect of mesenchymal stem cells in therapy of osteoporosis: a review. J Cell Physiol. 2019;234(6):8570-8.
8. Hartmann K, Koenen M, Schauer S, Wittig-Blaich S, Ahmad M, Baschant U, et al. Molecular actions of glucocorticoids in cartilage and bone during health, disease, and steroid therapy. Physiol Rev. 2016;96(2):409-47.

9. Oakley RH, Cidlowski JA. The biology of the glucocorticoid receptor: new signaling mechanisms in health and disease. J Allergy Clin Immunol. 2013; 132(5):1033-44.

10. Bollet AJ, Black R, Bunim JJ. Major undesirable side-effects resulting from prednisolone and prednisone. J Am Med Assoc. 1955;158(6):459-63.

11. Heimann WG, Freiberger RH. Avascular necrosis of the femoral and humeral heads after high-dosage corticosteroid therapy. N Engl J Med. 1960;263:672-5.

12. Weinstein RS. Clinical practice. Glucocorticoid-induced bone disease. N Engl J Med. 2011;365(1):62-70.

13. Weinstein RS. Glucocorticoid-induced osteonecrosis. Endocrine. 2012; 41(2):183-90

14. Houdek MT, Wyles CC, Packard BD, Terzic A, Behfar A, Sierra RJ. Decreased osteogenic activity of mesenchymal stem cells in patients with corticosteroid-induced osteonecrosis of the femoral head. J Arthroplast. 2016;31(4):893-8.

15. Rodriguez JP, Montecinos L, Rios S, Reyes P, Martinez J. Mesenchymal stem cells from osteoporotic patients produce a type I collagen-deficient extracellular matrix favoring adipogenic differentiation. J Cell Biochem. 2000; 79(4):557-65.

16. Li J, Zhang N, Huang X, Xu J, Fernandes JC, Dai K, et al. Dexamethasone shifts bone marrow stromal cells from osteoblasts to adipocytes by $\mathrm{C} /$ EBPalpha promoter methylation. Cell Death Dis. 2013;4:e832.

17. Friedenstein AJ, Gorskaja JF, Kulagina NN. Fibroblast precursors in normal and irradiated mouse hematopoietic organs. Exp Hematol. 1976;4(5):267-74.

18. da Silva ML, Caplan Al, Nardi NB. In search of the in vivo identity of mesenchymal stem cells. Stem Cells. 2008;26(9):2287-99.

19. Sacchetti B. Post-natal "mesenchymal" stem cells: the assayable skeletal potency. J Stem Cells Regenerative Med. 2019;15(1):12-5.

20. Elahi KC, Klein G, Avci-Adali M, Sievert KD, MacNeil S, Aicher WK. Human mesenchymal stromal cells from different sources diverge in their expression of cell surface proteins and display distinct differentiation patterns. Stem Cells Int. 2016;2016:5646384.

21. Kassem M, Bianco P. Skeletal stem cells in space and time. Cell. 2015; 160(1-2):17-9.

22. Kuznetsov SA, Mankani MH, Gronthos S, Satomura K, Bianco P, Robey PG. Circulating skeletal stem cells. J Cell Biol. 2001;153(5):1133-40.

23. Wilson A, Webster A, Genever P. Nomenclature and heterogeneity: consequences for the use of mesenchymal stem cells in regenerative medicine. Regenerative Med. 2019;14(6):595-611.

24. Rostovskaya M, Donsante S, Sacchetti B, Alexopoulou D, Klemroth S, Dahl A, et al. Clonal analysis delineates transcriptional programs of osteogenic and adipogenic lineages of adult mouse skeletal progenitors. Stem Cell Rep. 2018;11(1):212-27.

25. Chan CKF, Gulati GS, Sinha R, Tompkins JV, Lopez M, Carter AC, et al. Identification of the human skeletal stem cell. Cell. 2018;175(1):43-56 e21.

26. Chan CK, Seo EY, Chen JY, Lo D, McArdle A, Sinha R, et al. Identification and specification of the mouse skeletal stem cell. Cell. 2015;160(1-2):285-98.

27. Evans RM. The steroid and thyroid hormone receptor superfamily. Science. 1988;240(4854):889-95.

28. Mangelsdorf DJ, Thummel C, Beato M, Herrlich P, Schutz G, Umesono K, et al. The nuclear receptor superfamily: the second decade. Cell. 1995;83(6):835-9.

29. Kumar R, Thompson EB. Gene regulation by the glucocorticoid receptor: structure:function relationship. J Steroid Biochem Mol Biol. 2005;94(5):383-94.

30. Morishima Y, Kanelakis KC, Murphy PJ, Lowe ER, Jenkins GJ, Osawa Y, et al. The hsp90 cochaperone p23 is the limiting component of the multiprotein hsp90/hsp70-based chaperone system in vivo where it acts to stabilize the client protein: hsp90 complex. J Biol Chem. 2003;278(49):48754-63.

31. Pratt WB, Toft DO. Steroid receptor interactions with heat shock protein and immunophilin chaperones. Endocrine Rev. 1997;18(3):306-60.

32. Pratt $W B$, Toft $D O$. Regulation of signaling protein function and trafficking by the hsp90/hsp70-based chaperone machinery. Exp Biol Med (Maywood). 2003;228(2):111-33.

33. Grad I, Picard D. The glucocorticoid responses are shaped by molecular chaperones. Mol Cell Endocrinol. 2007;275(1-2):2-12.

34. Pratt WB. The role of heat shock proteins in regulating the function, folding, and trafficking of the glucocorticoid receptor. J Biol Chem. 1993;268(29): 21455-8. 
35. Smith DF, Toft DO. Steroid receptors and their associated proteins. Mol Endocrinol (Baltimore). 1993;7(1):4-11.

36. Scherrer LC, Picard D, Massa E, Harmon JM, Simons SS Jr, Yamamoto KR, et al. Evidence that the hormone binding domain of steroid receptors confers hormonal control on chimeric proteins by determining their hormone-regulated binding to heat-shock protein 90. Biochemistry. 1993; 32(20):5381-6

37. Rexin M, Busch W, Gehring U. Protein components of the nonactivated glucocorticoid receptor. J Biol Chem. 1991;266(36):24601-5.

38. Seckl JR. 11 beta-hydroxysteroid dehydrogenases: changing glucocorticoid action. Curr Opin Pharmacol. 2004;4(6):597-602.

39. Bamberger CM, Bamberger AM, de Castro M, Chrousos GP. Glucocorticoid receptor beta, a potential endogenous inhibitor of glucocorticoid action in humans. J Clin Investig. 1995;95(6):2435-41.

40. Ray DW, Davis JR, White A, Clark AJ. Glucocorticoid receptor structure and function in glucocorticoid-resistant small cell lung carcinoma cells. Cancer Res. 1996:56(14):3276-80.

41. Oakley RH, Sar M, Cidlowski JA. The human glucocorticoid receptor beta isoform. Expression, biochemical properties, and putative function. J Biol Chem. 1996;271(16):9550-9.

42. Nicolaides NC, Galata Z, Kino T, Chrousos GP, Charmandari E. The human glucocorticoid receptor: molecular basis of biologic function. Steroids. 2010; 75(1):1-12.

43. Encio IJ, Detera-Wadleigh SD. The genomic structure of the human glucocorticoid receptor. J Biol Chem. 1991;266(11):7182-8.

44. Hollenberg SM, Weinberger C, Ong ES, Cerelli G, Oro A, Lebo R, et al. Primary structure and expression of a functional human glucocorticoid receptor cDNA. Nature. 1985;318(6047):635-41.

45. Kelly A, Bowen H, Jee YK, Mahfiche N, Soh C, Lee T, et al. The glucocorticoid receptor beta isoform can mediate transcriptional repression by recruiting histone deacetylases. J Allergy Clin Immunol. 2008;121(1):203-8.e1.

46. Kim SH, Kim DH, Lavender P, Seo JH, Kim YS, Park JS, et al. Repression of TNF-alpha-induced IL-8 expression by the glucocorticoid receptorbeta involves inhibition of histone $\mathrm{H} 4$ acetylation. Exp Mol Med. 2009; 41(5):297-306

47. Li LB, Leung DY, Martin RJ, Goleva E. Inhibition of histone deacetylase 2 expression by elevated glucocorticoid receptor beta in steroid-resistant asthma. Am J Respir Crit Care Med. 2010;182(7):877-83.

48. Lewis-Tuffin LJ, Cidlowski JA. The physiology of human glucocorticoid receptor beta (hGRbeta) and glucocorticoid resistance. Ann N Y Acad Sci. 2006;1069:1-9.

49. Yun SP, Ryu JM, Han HJ. Involvement of beta1-integrin via PIP complex and FAK/paxillin in dexamethasone-induced human mesenchymal stem cells migration. J Cell Physiol. 2011;226(3):683-92.

50. Rivers C, Levy A, Hancock J, Lightman S, Norman M. Insertion of an amino acid in the DNA-binding domain of the glucocorticoid receptor as a result of alternative splicing. J Clin Endocrinol Metab. 1999:84(11):4283-6.

51. Haarman EG, Kaspers GJ, Pieters R, Rottier MM, Veerman AJ. Glucocorticoid receptor alpha, beta and gamma expression vs in vitro glucocorticod resistance in childhood leukemia. Leukemia. 2004;18(3):530-7.

52. Schiller BJ, Chodankar R, Watson LC, Stallcup MR, Yamamoto KR. Glucocorticoid receptor binds half sites as a monomer and regulates specific target genes. Genome Biol. 2014;15(7):418.

53. Moalli PA, Pillay S, Krett NL, Rosen ST. Alternatively spliced glucocorticoid receptor messenger RNAs in glucocorticoid-resistant human multiple myeloma cells. Cancer Res. 1993;53(17):3877-9.

54. de Lange P, Segeren CM, Koper JW, Wiemer E, Sonneveld P, Brinkmann AO, et al. Expression in hematological malignancies of a glucocorticoid receptor splice variant that augments glucocorticoid receptor-mediated effects in transfected cells. Cancer Res. 2001;61(10):3937-41.

55. Song M, Zhao D, Wei S, Liu C, Liu Y, Wang B, et al. The effect of electromagnetic fields on the proliferation and the osteogenic or adipogenic differentiation of mesenchymal stem cells modulated by dexamethasone. Bioelectromagnetics. 2014;35(7):479-90.

56. Xiao Y, Peperzak V, van Rijn L, Borst J, de Bruijn JD. Dexamethasone treatment during the expansion phase maintains stemness of bone marrow mesenchymal stem cells. J Tissue Eng Regen Med. 2010;4(5):374-86.

57. Gabet $Y$, Noh $T$, Lee $C$, Frenkel B. Developmentally regulated inhibition of cell cycle progression by glucocorticoids through repression of cyclin a transcription in primary osteoblast cultures. J Cell Physiol. 2011;226(4):991-8.
58. Monroe DG, McGee-Lawrence ME, Oursler MJ, Westendorf JJ. Update on Wnt signaling in bone cell biology and bone disease. Gene. 2012; 492(1):1-18

59. Smith E, Redman RA, Logg CR, Coetzee GA, Kasahara N, Frenkel B. Glucocorticoids inhibit developmental stage-specific osteoblast cell cycle. Dissociation of cyclin A-cyclin-dependent kinase 2 from E2F4-p130 complexes. J Biol Chem. 2000;275(26):19992-20001.

60. Li H, Qian W, Weng X, Wu Z, Li H, Zhuang Q, et al. Glucocorticoid receptor and sequential P53 activation by dexamethasone mediates apoptosis and cell cycle arrest of osteoblastic MC3T3-E1 cells. PLoS One. 2012;7(6):e37030.

61. Azuma K, Urano T, Ouchi Y, Inoue S. Glucocorticoid-induced gene tripartite motif-containing 63 (TRIM63) promotes differentiation of osteoblastic cells. Endocr J. 2010;57(5):455-62.

62. Kalak R, Zhou H, Street J, Day RE, Modzelewski JR, Spies CM, et al. Endogenous glucocorticoid signalling in osteoblasts is necessary to maintain normal bone structure in mice. Bone. 2009;45(1):61-7.

63. Eijken $M$, Koedam M, van Driel M, Buurman CJ, Pols HA, van Leeuwen JP. The essential role of glucocorticoids for proper human osteoblast differentiation and matrix mineralization. Mol Cell Endocrinol. 2006;248(1-2):87-93.

64. Zhou H, Mak W, Zheng Y, Dunstan CR, Seibel MJ. Osteoblasts directly control lineage commitment of mesenchymal progenitor cells through Wnt signaling. J Biol Chem. 2008;283(4):1936-45.

65. O'Brien CA, Jia D, Plotkin LI, Bellido T, Powers CC, Stewart SA, et al. Glucocorticoids act directly on osteoblasts and osteocytes to induce their apoptosis and reduce bone formation and strength. Endocrinology. 2004; 145(4):1835-41.

66. Grigoriadis AE, Heersche JN, Aubin JE. Differentiation of muscle, fat, cartilage, and bone from progenitor cells present in a bone-derived clonal cell population: effect of dexamethasone. J Cell Biol. 1988;106(6):2139-51.

67. Butler JS, Queally JM, Devitt BM, Murray DW, Doran PP, O'Byrne JM. Silencing Dkk1 expression rescues dexamethasone-induced suppression of primary human osteoblast differentiation. BMC Musculoskel Disord. 2010;11:210.

68. Ohnaka K, Tanabe M, Kawate H, Nawata H, Takayanagi R. Glucocorticoid suppresses the canonical Wnt signal in cultured human osteoblasts. Biochem Biophys Res Commun. 2005;329(1):177-81.

69. Mak W, Shao X, Dunstan CR, Seibel MJ, Zhou H. Biphasic glucocorticoiddependent regulation of Wnt expression and its inhibitors in mature osteoblastic cells. Calcified Tissue Int. 2009;85(6):538-45.

70. Wang FS, Lin CL, Chen YJ, Wang CJ, Yang KD, Huang YT, et al. Secreted frizzled-related protein 1 modulates glucocorticoid attenuation of osteogenic activities and bone mass. Endocrinology. 2005;146(5):2415-23.

71. Yao W, Cheng Z, Busse C, Pham A, Nakamura MC, Lane NE. Glucocorticoid excess in mice results in early activation of osteoclastogenesis and adipogenesis and prolonged suppression of osteogenesis: a longitudinal study of gene expression in bone tissue from glucocorticoid-treated mice. Arthritis Rheumatism. 2008;58(6):1674-86.

72. Wang FS, Ko JY, Yeh DW, Ke HC, Wu HL. Modulation of Dickkopf-1 attenuates glucocorticoid induction of osteoblast apoptosis, adipocytic differentiation, and bone mass loss. Endocrinology. 2008;149(4):1793-801.

73. Luppen CA, Smith E, Spevak L, Boskey AL, Frenkel B. Bone morphogenetic protein-2 restores mineralization in glucocorticoid-inhibited MC3T3-E1 osteoblast cultures. J Bone Miner Res. 2003;18(7):1186-97.

74. Hayashi K, Yamaguchi T, Yano S, Kanazawa I, Yamauchi M, Yamamoto M, et al. BMP/Wnt antagonists are upregulated by dexamethasone in osteoblasts and reversed by alendronate and PTH: potential therapeutic targets for glucocorticoid-induced osteoporosis. Biochem Biophys Res Commun. 2009:379(2):261-6.

75. Pereira RM, Delany AM, Durant D, Canalis E. Cortisol regulates the expression of notch in osteoblasts. J Cell Biochem. 2002;85(2):252-8.

76. Zanotti S, Yu J, Adhikari S, Canalis E. Glucocorticoids inhibit notch target gene expression in osteoblasts. J Cell Biochem. 2018;119(7):6016-23.

77. Chang DJ, Ji C, Kim KK, Casinghino S, McCarthy TL, Centrella M. Reduction in transforming growth factor beta receptor I expression and transcription factor CBFa1 on bone cells by glucocorticoid. J Biol Chem. 1998;273(9):4892-6.

78. Koromila T, Baniwal SK, Song YS, Martin A, Xiong J, Frenkel B. Glucocorticoids antagonize RUNX2 during osteoblast differentiation in cultures of ST2 pluripotent mesenchymal cells. J Cell Biochem. 2014;115(1):27-33.

79. Lin L, Dai SD, Fan GY. Glucocorticoid-induced differentiation of primary cultured bone marrow mesenchymal cells into adipocytes is antagonized by exogenous Runx2. APMIS. 2010;118(8):595-605. 
80. Cao Z, Umek RM, McKnight SL. Regulated expression of three C/EBP isoforms during adipose conversion of 3T3-L1 cells. Genes Dev. 1991; 5(9):1538-52.

81. Carcamo-Orive I, Gaztelumendi A, Delgado J, Tejados N, Dorronsoro A, Fernandez-Rueda J, et al. Regulation of human bone marrow stromal cell proliferation and differentiation capacity by glucocorticoid receptor and AP-1 crosstalk. J Bone Miner Res. 2010; 25(10):2115-25.

82. Pereira RC, Delany AM, Canalis E. Effects of cortisol and bone morphogenetic protein-2 on stromal cell differentiation: correlation with CCAAT-enhancer binding protein expression. Bone. 2002;30(5):685-91.

83. Hong D, Chen HX, Xue Y, Li DM, Wan XC, Ge R, et al. Osteoblastogenic effects of dexamethasone through upregulation of TAZ expression in rat mesenchymal stem cells. J Steroid Biochem Mol Biol. 2009;116(1-2):86-92.

84. He Q, Huang HY, Zhang YY, Li X, Qian SW, Tang QQ. TAZ is downregulated by dexamethasone during the differentiation of 3T3-L1 preadipocytes. Biochem Biophys Res Commun. 2012;419(3):573-7.

85. Ayroldi E, Macchiarulo A, Riccardi C. Targeting glucocorticoid side effects: selective glucocorticoid receptor modulator or glucocorticoid-induced leucine zipper? A perspective. FASEB J. 2014;28(12):5055-70.

86. Zhang W, Yang N, Shi XM. Regulation of mesenchymal stem cell osteogenic differentiation by glucocorticoid-induced leucine zipper (GILZ). J Biol Chem. 2008;283(8):4723-9.

87. Pan G, Cao J, Yang N, Ding K, Fan C, Xiong WC, et al. Role of glucocorticoid-induced leucine zipper (GIIZ) in bone acquisition. J Biol Chem. 2014;289(28):19373-82.

88. Shi X, Shi W, Li Q, Song B, Wan M, Bai S, et al. A glucocorticoid-induced leucine-zipper protein, GILZ, inhibits adipogenesis of mesenchymal cells. EMBO Rep. 2003;4(4):374-80,

89. Noack C, Hempel U, Preissler C, Dieter P. Prostaglandin E2 impairs osteogenic and facilitates adipogenic differentiation of human bone marrow stromal cells. Prostaglandins Leukot Essent Fatty Acids. 2015;94:91-8.

90. Tan K, Peng YT, Guo P. MiR-29a promotes osteogenic differentiation of mesenchymal stem cells via targeting HDAC4. Eur Rev Med Pharmacol Sci. 2018;22(11):3318-26.

91. Kapinas K, Kessler C, Ricks T, Gronowicz G, Delany AM. miR-29 modulates Wnt signaling in human osteoblasts through a positive feedback loop. J Biol Chem. 2010;285(33):25221-31.

92. Wang FS, Chuang PC, Lin CL, Chen MW, Ke HJ, Chang YH, et al. MicroRNA29a protects against glucocorticoid-induced bone loss and fragility in rats by orchestrating bone acquisition and resorption. Arthritis Rheumatism. 2013;65(6):1530-40.

93. Li T, Li H, Li T, Fan J, Zhao RC, Weng X. MicroRNA expression profile of dexamethasone-induced human bone marrow-derived mesenchymal stem cells during osteogenic differentiation. J Cell Biochem. 2014; 115(10):1683-91.

94. Li H, Li T, Fan J, Li T, Fan L, Wang S, et al. miR-216a rescues dexamethasone suppression of osteogenesis, promotes osteoblast differentiation and enhances bone formation, by regulating c-Cbl-mediated PI3KVAKT pathway. Cell Death Differ. 2015;22(12):1935-45.

95. Hao C, Yang S, Xu W, Shen JK, Ye S, Liu X, et al. MiR-708 promotes steroidinduced osteonecrosis of femoral head, suppresses osteogenic differentiation by targeting SMAD3. Sci Rep. 2016;6:22599.

96. Shang G, Wang Y, Xu Y, Zhang S, Sun X, Guan H, et al. Long non-coding RNA TCONS_00041960 enhances osteogenesis and inhibits adipogenesis of rat bone marrow mesenchymal stem cell by targeting miR-204-5p and miR125a-3p. J Cell Physiol. 2018;233(8):6041-51.

97. Xiang S, Li Z, Weng X. The role of IncRNA RP11-154D6 in steroid-induced osteonecrosis of the femoral head through BMSC regulation. J Cell Biochem. 2019;120(10):18435-45.

98. Almeida M, Han L, Ambrogini E, Weinstein RS, Manolagas SC. Glucocorticoids and tumor necrosis factor alpha increase oxidative stress and suppress Wht protein signaling in osteoblasts. J Biol Chem. 2011; 286(52):44326-35.

99. Feng $\mathrm{YL}$, Tang $\mathrm{XL}$. Effect of glucocorticoid-induced oxidative stress on the expression of Cbfa1. Chem Biol Interact. 2014;207:26-31.

100. Yu H, Tay CY, Leong WS, Tan SC, Liao K, Tan LP. Mechanical behavior of human mesenchymal stem cells during adipogenic and osteogenic differentiation. Biochem Biophys Res Commun. 2010;393(1):150-5.

101. Bellido T. Antagonistic interplay between mechanical forces and glucocorticoids in bone: a tale of kinases. J Cell Biochem. 2010;111(1):1-6.
102. Logan CY, Nusse R. The Wnt signaling pathway in development and disease. Ann Rev Cell Dev Biol. 2004;20:781-810.

103. Muruganandan S, Roman AA, Sinal CJ. Adipocyte differentiation of bone marrow-derived mesenchymal stem cells: cross talk with the osteoblastogenic program. Cell Mol Life Sci. 2009;66(2):236-53.

104. Park HW, Kim YC, Yu B, Moroishi T, Mo JS, Plouffe SW, et al. Alternative Wnt signaling activates YAP/TAZ. Cell. 2015;162(4):780-94.

105. Yuan Z, Li Q, Luo S, Liu Z, Luo D, Zhang B, et al. PPARgamma and Wnt signaling in adipogenic and osteogenic differentiation of mesenchymal stem cells. Curr Stem Cell Res Ther. 2016;11(3):216-25.

106. Brunetti G, Faienza MF, Piacente L, Ventura A, Oranger A, Carbone C, et al. High dickkopf-1 levels in sera and leukocytes from children with 21hydroxylase deficiency on chronic glucocorticoid treatment. Am J Physiol Endocrinol Metab. 2013;304(5):E546-54.

107. Kang Q, Song WX, Luo Q, Tang N, Luo J, Luo X, et al. A comprehensive analysis of the dual roles of BMPs in regulating adipogenic and osteogenic differentiation of mesenchymal progenitor cells. Stem Cells Dev. 2009;18(4):545-59.

108. Chen G, Deng C, Li YP. TGF-beta and BMP signaling in osteoblast differentiation and bone formation. Int J Biol Sci. 2012;8(2):272-88.

109. Deng ZL, Sharff KA, Tang N, Song WX, Luo J, Luo X, et al. Regulation of osteogenic differentiation during skeletal development. Front Biosci. 2008; 13:2001-21.

110. Gori F, Thomas T, Hicok KC, Spelsberg TC, Riggs BL. Differentiation of human marrow stromal precursor cells: bone morphogenetic protein-2 increases OSF2/CBFA1, enhances osteoblast commitment, and inhibits late adipocyte maturation. J Bone Miner Res. 1999;14(9):1522-35.

111. Otsuki Y, li M, Moriwaki K, Okada M, Ueda K, Asahi M. W9 peptide enhanced osteogenic differentiation of human adipose-derived stem cells. Biochem Biophys Res Commun. 2018;495(1):904-10.

112. Artavanis-Tsakonas S, Matsuno K, Fortini ME. Notch signaling. Science. 1995; 268(5208):225-32.

113. Ehebauer M, Hayward P, Arias AM. Notch, a universal arbiter of cell fate decisions. Science. 2006;314(5804):1414-5.

114. Ehebauer M, Hayward P, Martinez-Arias A. Notch signaling pathway. Sci STKE. 2006;2006(364):cm7.

115. Chiba S. Notch signaling in stem cell systems. Stem Cells. 2006;24(11):2437-47.

116. Zanotti S, Canalis E. Notch signaling and the skeleton. Endocrine Rev. 2016; 37(3):223-53.

117. D'Souza B, Meloty-Kapella L, Weinmaster G. Canonical and non-canonical notch ligands. Curr Topics Dev Biol. 2010;92:73-129.

118. Siebel C, Lendahl U. Notch signaling in development, tissue homeostasis, and disease. Physiol Rev. 2017;97(4):1235-94.

119. Ross DA, Rao PK, Kadesch T. Dual roles for the notch target gene Hes-1 in the differentiation of 3T3-L1 preadipocytes. Mol Cell Biol. 2004:24(8):3505-13.

120. Nobta M, Tsukazaki T, Shibata Y, Xin C, Moriishi T, Sakano S, et al. Critical regulation of bone morphogenetic protein-induced osteoblastic differentiation by Delta1/Jagged1-activated Notch1 signaling. J Biol Chem. 2005:280(16):15842-8.

121. Deregowski V, Gazzerro E, Priest L, Rydziel S, Canalis E. Notch 1 overexpression inhibits osteoblastogenesis by suppressing Wnt/beta-catenin but not bone morphogenetic protein signaling. J Biol Chem. 2006;281(10):6203-10.

122. Kung AW, Xiao SM, Cherny S, Li GH, Gao Y, Tso G, et al. Association of JAG1 with bone mineral density and osteoporotic fractures: a genome-wide association study and follow-up replication studies. Am J Hum Genet. 2010; 86(2):229-39.

123. Ducy P, Starbuck M, Priemel M, Shen J, Pinero G, Geoffroy V, et al. A Cbfa1dependent genetic pathway controls bone formation beyond embryonic development. Genes Dev. 1999;13(8):1025-36.

124. Karsenty G. Role of Cbfa1 in osteoblast differentiation and function. Semin Cell Dev Biol. 2000;11(5):343-6.

125. Komori T. Regulation of osteoblast differentiation by transcription factors. J Cell Biochem. 2006;99(5):1233-9.

126. Komori T, Yagi H, Nomura S, Yamaguchi A, Sasaki K, Deguchi K, et al. Targeted disruption of Cbfa1 results in a complete lack of bone formation owing to maturational arrest of osteoblasts. Cell. 1997;89(5):755-64.

127. Lefterova MI, Zhang Y, Steger DJ, Schupp M, Schug J, Cristancho A, et al. PPARgamma and C/EBP factors orchestrate adipocyte biology via adjacent binding on a genome-wide scale. Genes Dev. 2008;22(21):2941-52.

128. Kushwaha P, Khedgikar V Gautam J, Dixit P, Chillara R, Verma A et al. A novel therapeutic approach with Caviunin-based isoflavonoid that en routes 
bone marrow cells to bone formation via BMP2/Wnt-beta-catenin signaling. Cell Death Dis. 2014;5:e1422.

129. Kim J, Ko J. A novel PPARgamma2 modulator sLZIP controls the balance between adipogenesis and osteogenesis during mesenchymal stem cell differentiation. Cell Death Differ. 2014;21(10):1642-55.

130. Hong JH, Hwang ES, McManus MT, Amsterdam A, Tian Y, Kalmukova R, et al. TAZ, a transcriptional modulator of mesenchymal stem cell differentiation. Science. 2005;309(5737):1074-8.

131. Hong JH, Yaffe MB. TAZ: a beta-catenin-like molecule that regulates mesenchymal stem cell differentiation. Cell Cycle. 2006; 5(2):176-9.

132. Kanai F, Marignani PA, Sarbassova D, Yagi R, Hall RA, Donowitz M, et al. TAZ: a novel transcriptional co-activator regulated by interactions with 14-3-3 and PDZ domain proteins. EMBO J. 2000;19(24):6778-91.

133. D'Adamio F, Zollo O, Moraca R, Ayroldi E, Bruscoli S, Bartoli A, et al. A new dexamethasone-induced gene of the leucine zipper family protects T lymphocytes from TCR/CD3-activated cell death. Immunity. 1997;7(6):803-12.

134. Eddleston J, Herschbach J, Wagelie-Steffen AL, Christiansen SC, Zuraw BL. The anti-inflammatory effect of glucocorticoids is mediated by glucocorticoid-induced leucine zipper in epithelial cells. J Allergy Clin Immunol. 2007;119(1):115-22.

135. Yang N, Zhang W, Shi XM. Glucocorticoid-induced leucine zipper (GILZ) mediates glucocorticoid action and inhibits inflammatory cytokine-induced COX-2 expression. J Cell Biochem. 2008;103(6):1760-71.

136. Beaulieu E, Ngo D, Santos L, Yang YH, Smith M, Jorgensen C, et al. Glucocorticoid-induced leucine zipper is an endogenous antiinflammatory mediator in arthritis. Arthritis Rheumatism. 2010;62(9):2651-61.

137. Blackwell KA, Raisz LG, Pilbeam CC. Prostaglandins in bone: bad cop, good cop? Trends Endocrinol Metab. 2010;21(5):294-301.

138. Legler DF, Bruckner M, Uetz-von Allmen E, Krause P. Prostaglandin E2 at new glance: novel insights in functional diversity offer therapeutic chances. Int J Biochem Cell Biol. 2010;42(2):198-201.

139. Mourelatos Z. Small RNAs: the seeds of silence. Nature. 2008:455(7209):44-5.

140. Rodriguez A, Griffiths-Jones S, Ashurst JL, Bradley A. Identification of mammalian microRNA host genes and transcription units. Genome Res. 2004;14(10a):1902-10.

141. Erson AE, Petty EM. MicroRNAs in development and disease. Clin Genet. 2008;74(4):296-306.

142. Oskowitz AZ, Lu J, Penfornis P, Ylostalo J, McBride J, Flemington EK, et al. Human multipotent stromal cells from bone marrow and microRNA: regulation of differentiation and leukemia inhibitory factor expression. Proc Natl Acad Sci U S A. 2008;105(47):18372-7.

143. Ivey KN, Srivastava D. MicroRNAs as regulators of differentiation and cell fate decisions. Cell Stem Cell. 2010;7(1):36-41.

144. Kashi K, Henderson L, Bonetti A, Carninci P. Discovery and functional analysis of IncRNAs: methodologies to investigate an uncharacterized transcriptome. Biochim Biophys Acta. 2016;1859(1):3-15.

145. Wapinski O, Chang HY. Long noncoding RNAs and human disease. Trends Cell Biol. 2011;21(6):354-61.

146. Guttman M, Rinn JL. Modular regulatory principles of large non-coding RNAs. Nature. 2012;482(7385):339-46.

147. Yoshioka H, Yoshiko Y. The Roles of Long Non-Protein-Coding RNAs in Osteo-Adipogenic Lineage Commitment. Int J Mol Sci. 2017;18(6):14.

148. Chen C, Cui Q, Zhang X, Luo X, Liu Y, Zuo J, et al. Long non-coding RNAs regulation in adipogenesis and lipid metabolism: emerging insights in obesity. Cell Signal. 2018;51:47-58.

149. Zhang J, Hao X, Yin M, Xu T, Guo F. Long non-coding RNA in osteogenesis: a new world to be explored. Bone Joint Res. 2019:8(2):73-80.

150. Atashi F, Modarressi A, Pepper MS. The role of reactive oxygen species in mesenchymal stem cell adipogenic and osteogenic differentiation: a review. Stem Cells Dev. 2015;24(10):1150-63.

151. Stolzing A, Jones E, McGonagle D, Scutt A. Age-related changes in human bone marrow-derived mesenchymal stem cells: consequences for cell therapies. Mecha Ageing Dev. 2008;129(3):163-73.

152. Almeida M, Ambrogini E, Han L, Manolagas SC, Jilka RL. Increased lipid oxidation causes oxidative stress, increased peroxisome proliferatoractivated receptor-gamma expression, and diminished pro-osteogenic Wnt signaling in the skeleton. J Biol Chem. 2009;284(40):27438-48.

153. Kousteni S. FoxO1, the transcriptional chief of staff of energy metabolism. Bone. 2012;50(2):437-43.
154. Zhang Y, Marsboom G, Toth PT, Rehman J. Mitochondrial respiration regulates adipogenic differentiation of human mesenchymal stem cells. PLoS One. 2013;8(10):e77077.

155. Qiu X, Wang X, Qiu J, Zhu Y, Liang T, Gao B, et al. Melatonin rescued reactive oxygen species-impaired osteogenesis of human bone marrow mesenchymal stem cells in the presence of tumor necrosis factor-alpha. Stem Cells Int. 2019;2019:6403967.

156. Sun N, Yang L, Li Y, Zhang H, Chen H, Liu D, et al. Effect of advanced oxidation protein products on the proliferation and osteogenic differentiation of rat mesenchymal stem cells. Int J Mol Med. 2013;32(2):485-91.

157. Darling EM, Topel M, Zauscher S, Vail TP, Guilak F. Viscoelastic properties of human mesenchymally-derived stem cells and primary osteoblasts, chondrocytes, and adipocytes. J Biomechanics. 2008;41(2):454-64.

158. Li R, Liang L, Dou Y, Huang Z, Mo H, Wang Y, et al. Mechanical strain regulates osteogenic and adipogenic differentiation of bone marrow mesenchymal stem cells. Biomed Res Int. 2015;2015:873251.

159. Cunningham CC, Gorlin JB, Kwiatkowski DJ, Hartwig JH, Janmey PA, Byers $H R$, et al. Actin-binding protein requirement for cortical stability and efficient locomotion. Science. 1992;255(5042):325-7.

160. Stossel TP, Condeelis J, Cooley L, Hartwig JH, Noegel A, Schleicher M, et al. Filamins as integrators of cell mechanics and signalling. Nat Rev Mol Cell Biol. 2001;2(2):138-45.

161. van der Flier A, Sonnenberg A. Structural and functional aspects of filamins. Biochim Biophys Acta. 2001;1538(2-3):99-117.

162. D'Addario M, Arora PD, Fan J, Ganss B, Ellen RP, McCulloch CA. Cytoprotection against mechanical forces delivered through beta 1 integrins requires induction of filamin A. J Biol Chem. 2001;276(34):31969-77.

163. D'Addario M, Arora PD, Ellen RP, McCulloch CA. Interaction of p38 and Sp1 in a mechanical force-induced, beta 1 integrin-mediated transcriptional circuit that regulates the actin-binding protein filamin-A. J Biol Chem. 2002; 277(49):47541-50.

164. Ohta Y, Hartwig JH, Stossel TP. FilGAP, a Rho- and ROCK-regulated GAP for Rac binds filamin A to control actin remodelling. Nature Cell Biol. 2006;8(8):803-14.

165. Shifrin Y, Arora PD, Ohta Y, Calderwood DA, McCulloch CA. The role of FilGAPfilamin A interactions in mechanoprotection. Mol Biol Cell. 2009;20(5):1269-79.

166. Plotkin LI, Mathov I, Aguirre JI, Parfitt AM, Manolagas SC, Bellido T. Mechanical stimulation prevents osteocyte apoptosis: requirement of integrins, Src kinases, and ERKs. Am J Physiol Cell Physiol. 2005;289(3):C633-43.

167. Plotkin LI, Manolagas SC, Bellido T. Glucocorticoids induce osteocyte apoptosis by blocking focal adhesion kinase-mediated survival. Evidence for inside-out signaling leading to anoikis. J Biol Chem. 2007;282(33):24120-30.

168. Tang QQ, Lane MD. Adipogenesis: from stem cell to adipocyte. An Rev Biochem. 2012;81:715-36.

169. Chen Q, Shou P, Zheng C, Jiang M, Cao G, Yang Q et al. Fate decision of mesenchymal stem cells: adipocytes or osteoblasts? Cell Death Differ. 2016;23(7):1128-39.

170. Rauch A, Gossye V, Bracke D, Gevaert E, Jacques P, Van Beneden K, et al. An anti-inflammatory selective glucocorticoid receptor modulator preserves osteoblast differentiation. FASEB J. 2011:25(4):1323-32.

171. Thiele S, Ziegler N, Tsourdi E, De Bosscher K, Tuckermann JP, Hofbauer LC, et al. Selective glucocorticoid receptor modulation maintains bone mineral density in mice. J Bone Miner Res. 2012;27(11):2242-50.

172. Reid IR. Targeting Sclerostin in postmenopausal osteoporosis: focus on Romosozumab and Blosozumab. BioDrugs. 2017;31(4):289-97.

173. Ko JY, Chuang PC, Chen MW, Ke HC, Wu SL, Chang YH, et al. MicroRNA-29a ameliorates glucocorticoid-induced suppression of osteoblast differentiation by regulating beta-catenin acetylation. Bone. 2013;57(2):468-75.

174. Hu C, Zhao L, Peng C, Li L. Regulation of the mitochondrial reactive oxygen species: strategies to control mesenchymal stem cell fates ex vivo and in vivo. J Cell Mol Med. 2018:22(11):5196-207.

175. Alhadlaq A, Mao JJ. Mesenchymal stem cells: isolation and therapeutics. Stem Cells Dev. 2004;13(4):436-48.

176. Samsonraj RM, Raghunath M, Nurcombe V, Hui JH, van Wijnen AJ, Cool SM. Concise review: multifaceted characterization of human mesenchymal stem cells for use in regenerative medicine. Stem Cells Transl Med. 2017;6(12):2173-85.

177. Sung JH, An HS, Jeong JH, Shin S, Song SY. Megestrol acetate increases the proliferation, migration, and adipogenic differentiation of adipose-derived stem cells via glucocorticoid receptor. Stem Cells Transl Med. 2015;4(7):789-99.

\section{Publisher's Note}

Springer Nature remains neutral with regard to jurisdictional claims in published maps and institutional affiliations. 